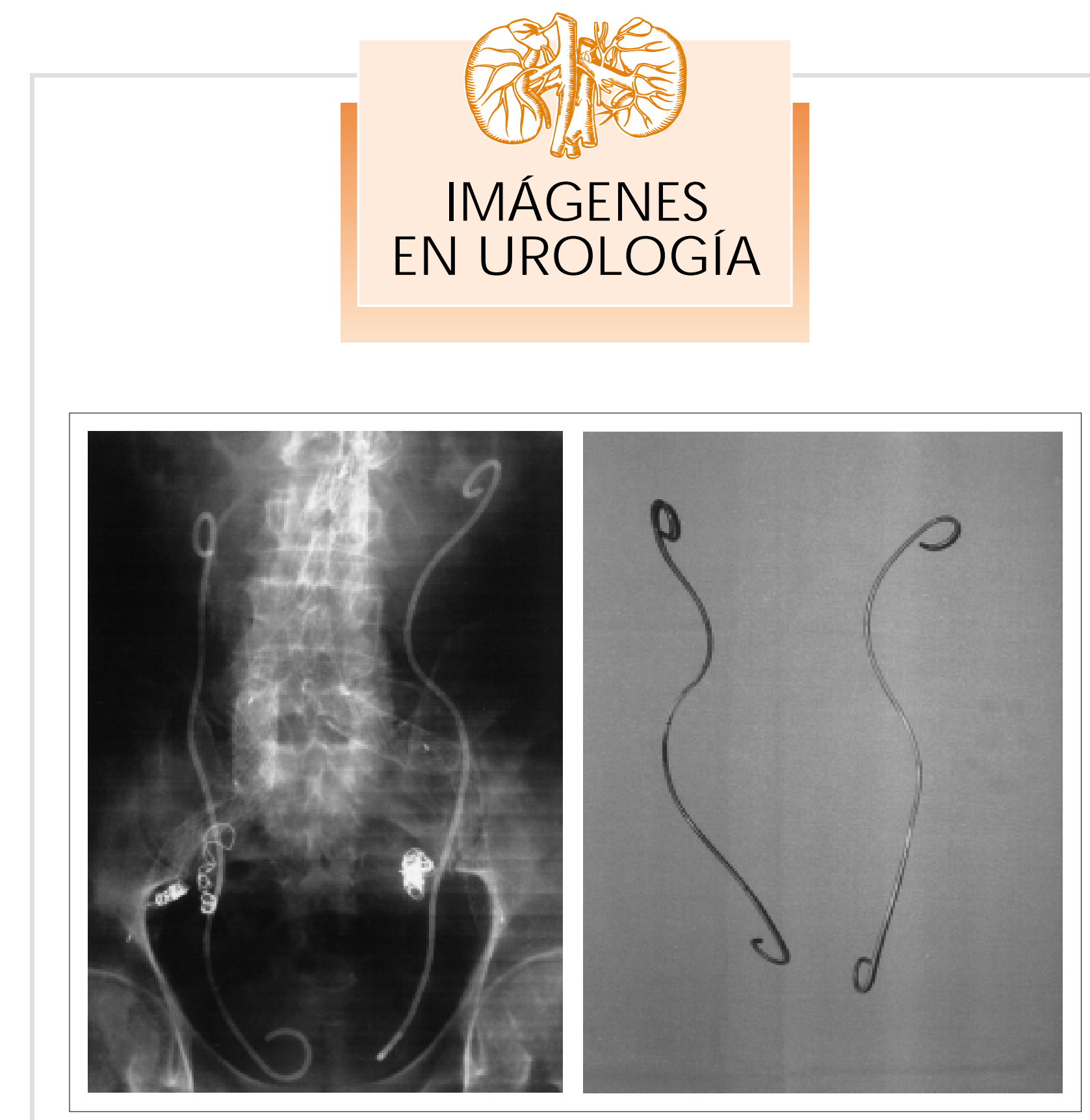

\title{
SONDAS DOBLE J: 4 AÑOS DE EVOLUCIÓN
}

Los catéteres ureterales "olvidados" durante más de 6 meses presentan un riesgo de calcificación, fragmentación y/o migración muy elevado ( $>85 \%)$ requiriendo generalmente para su extracción de manipulaciones endourológicas, percutáneas, litotricia extracorpórea e incluso cirugia abierta.

Resulta curiosa la radiografía pélvica de este paciente afecto de fibrosis retroperitoneal secundaria a cirugía de aneurisma aórtico y que es portador de stents vasculares en toda la aorta infrarrenal y abas iliacas comunes además de coils obstructivos en las arterias hipogástricas. Sin embargo, lo más llamativo resulta la ausencia de calcificaciones $u$ otras alteraciones en unas sondas doble $J$ que han permanecido dentro del sistema urinario durante 51 meses. El examen fisico de las mismas confirmó su completa normalidad. 